Sains Malaysiana 49(6)(2020): 1451-1460

http://dx.doi.org/10.17576/jsm-2020-4906-23

\title{
Ab-initio Calculations of the Structural, Electronic and Optical Properties of $(\mathrm{CdSe})_{2}$ Clusters

\author{
(Penghitungan Ab-initio Sifat Struktur, Elektronik dan Optikal Kelompok $\left.(\mathrm{CdSe})_{2}\right)$
}

A.I.A. AlSelaWE*, MhH Jumali, G. GopiR \& M.M. ANAS

\begin{abstract}
The distinctive properties of cadmium selenide (CdSe) semiconductor situated it in a multitudinous number of applications. Although (CdSe), cluster has more than one isomer, the previous studies concentrated merely on one isomer. The goal of this study was to determine the various stable geometric structure isomers of (CdSe) ${ }_{2}$ clusters; also, structural, electronic, and optical properties of the stable isomers are investigated using density functional theory (DFT). First, geometry optimization calculations of the possible geometric isomers were carried out using the BroydenFletcher-Goldfarb-Shanno minimization (BFGS) algorithm. Total ground-state energy calculations showed that all the converged isomers have a high probability of existing in any experiment, relying on the implemented experimental technique. Twenty initial possible geometric structures were investigated, in which eleven isomers were converged. However, all of them are relaxed in the 2D planar geometry. The results showed that eleven possible stable isomers were disclosed, where the final structures of the converged isomers produced six different structures; three of them were not detected before. The rhombus structure was ascertained to be the most stable isomer followed by the trapezoidal structure of (CdSe). The isomers' $\mathrm{Cd}$-Se bond length are 2.50-2.74 A, and the average $\mathrm{Cd}$-Se-Cd, Se-Cd-Se angles were $64.5^{\circ}-123^{\circ}$ and $56.3^{\circ}-114.2^{\circ}$, respectively. Furthermore, the bond angles show that the selenium atom lone-pairs electrons are responsible for shifting the isomers'structure from the linearity. The total ground-state energy differences were 0.00-1.82 eV. The calculated highest occupied molecular orbital (HOMO), and the lowest unoccupied molecular orbital (LUMO) gap of the isomers implied that the gap depends on the symmetrical geometry of the isomer. Furthermore, it was evident that the most stable isomers are accompanied with larger gaps. The HOMO-LUMO graphs demonstrated that HOMO orbitals were localized around the selenium atom, while LUMO orbitals were distributed around both cadmium and selenium atoms. The calculated absorption spectrum was unique for each isomer. The absorption edges for the isomers are ranging from 2.53 to $3.73 \mathrm{eV}$. The results show that the obtained absorption spectra peaks' values $(\mathrm{nm})$ are smaller compared to $\mathrm{CdSe}$ experimental results. $(\mathrm{CdSe})_{2}$ clusters are very active that they straightforwardly react to produce larger clusters. Finally, the results of this study corroborate with previous computational studies.
\end{abstract}

Keywords: Cluster; dimer cadmium selenide; geometry optimization; isomer; rhombus structure

\section{ABSTRAK}

Keunggulan sifat semikonduktur kadmium selenida (CdSe) menjadikannya memiliki pelbagai aplikasi dalam bidang elektronik. Meskipun kelompok (CdSe), mempunyai lebih daripada satu isomer, namun kajian sebelum ini hanya melaporkan satu isomer sahaja. Tujuan kajian ini dijalankan adalah untuk menentukan kepelbagaian isomer geometri kelompok (CdSe), disamping sifat struktur, elektronik dan pencirian sifat optik ditentukan menggunakan teori fungsian ketumpatan (DFT). Pertama pengiraan pengoptimumam sifat geometri ditentukan menggunakan algoritma BroydenFletcher-Geodecker-Shannov(BFGS). Jumlah tenaga keadaan dasar menunjukkan kebarangkalian setiap isomer wujud dalam kajian beruji kaji adalah tinggi, namun bergantung kepada jenis uji kaji yang dijalankan. Sejumlah sebelas daripada dua puluh struktur geometri awal yang dikaji telah berjaya. Manakala semua struktur geometri tersebut menunjukkan keadaan di satah 2D. Keputusan menunjukkan enam daripada sebelas struktur tersebut telah dilaporkan dalam keputusan kajian yang lepas, manakala tiga selebihnya belum dilaporkan sebelum ini. Struktur rombus memberikan keadaan struktur isomer yang paling stabil diikuti dengan struktur trapezoidal (CdSe). Panjang ikatan isomer antara $\mathrm{Cd}$-Se adalah 2.5-2.74 A dan purata sudut antara $\mathrm{Cd}$-Se-Cd serta $\mathrm{Se}-\mathrm{Cd}$-Se adalah $64.5^{\circ}-123^{\circ}$ dan $56.3^{\circ}$ $114.2^{\circ}$. Tambahan pula, sudut ikatan menunjukkan elektron yang tidak terikat pada atom selenium memainkan peranan mengubah struktur isomer daripada bersifat struktur linear. Jumlah perbezaan jurang nilai tenaga dalam keadaan dasar adalah sekitar 0.00-1.82 eV. Penentuan nilai jarak antara tenaga molekul orbit yang dihuni (HOMO) dan molekul orbit yang tidak dihuni (LUMO) bergantung kepada sifat geometri isomer yang bersimetri. Keputusan kajian menunjukkan isomer yang paling stabil mempunyai nilai jurang tenaga yang lebih besar. Graf taburan elektron menunjukkan orbit HОМO tertumpu di sekitar atom selenium, sementara orbit LUMO terletak di sekitar atom kadmium dan selenium. 
Spektrum serapan bagi setiap isomer adalah unik antara satu sama lain. Nilai tenaga serapan bermula sekitar 2.53 hingga $3.73 \mathrm{eV}$. Hasil kajian menunjukkan nilai tenaga pada puncak serapan adalah rendah sedikit berbanding kajian yang dilaporkan dalam kajian CdSe secara uji kaji disebabkan kelompok (CdSe), amat reaktif sehingga membentuk kelompok yang lebih besar. Kesimpulannya, keputusan kajian semasa memberi nilai sokongan kepada keputusan kajian komputasi yang lepas.

Kata kunci: Isomer; kadmium selenida dimer; kelompok; pengoptimum geometri; struktur rombus

\section{INTRODUCTION}

The recent speed-up advances in nanoscale science opened an interesting way to deeply study the diverse properties of the nanocluster's entities. In addition, the unending miniaturization process requires in-depth research, touching even fundamental issues. The quantum confinement effect induces a new character to the parent material, which yields new electronic and optical properties. These nanocrystals' properties are size-dependent; the optical and electronic properties can be tuned by just changing its size, shape, composition, or adding a ligand. The applications with which these nanoclusters can participate in are wide and increasing. The nanoclusters regime is the natural link between molecular and bulk phases. Understanding their properties can assist in explaining other larger structures such as nanobelts, nanowires, nanotubes, nanorods, and quantum dots. This will carry a significance for developing and enhancing wide potential applications.

Cadmium selenide (CdSe) semiconductor compound, either as bulk or nanocrystal form, is one of the II-VI compounds that have been extensively studied due to its extraordinary features. CdSe nanocrystals exhibit a mixed ionic-covalent bond, wide band-gap, narrow-emission peak, high photoluminescence and notable chemical stability, which led to placing it in a significant position compared with other nanostructure counterparts (Chen et al. 2013; Majdabadi et al. 2015; Yu \& Cardona 2010). The unique optical properties introduced $\mathrm{CdSe}$ into many optoelectronic devices. Light-emitting diodes, sensors, lasers, displays, medical imaging, transistors, high-speed integrated circuits, and solar cells are well-known examples of their boundless practical applications (Alivisatos 2003; Atchison \& Schauer 2011; Kilina et al. 2015; Kim et al. 2011; Lee et al. 2017; Renner et al. 2006; Schreuder et al. 2010; Stinner et al. 2015; Tao et al. 2016). Although it is difficult neither to synthesize the gas phase of the nanoclusters nor to be persisted a long time under normal conditions, there were remarkable advances in synthesizing CdSe nanoclusters that were very close to the atomic size (Kolobkova et al. 2015). Cossairt and Owen (2011) succeeded in producing a $4 \mathrm{~nm}$ CdSe nanocrystals from clusters building blocks, which exhibit exceptional thermodynamic stability. Kolobkova et al. (2015) displayed the formation of (CdSe) $)_{n}$ subnanosized molecular clusters, which exhibit luminescent in the visible region. These nanoclusters then formed very small $(>1 \mathrm{~nm})$ CdSe quantum dots. Kisslinger et al. (2017) concluded that II-VI quantum dots based solar cells would develop more efficient solar cells. Also, some works reported successfully produced nanoscale structures with prominent different features from the parent bulk material (Yu-Zhang et al. 2008).

Atomic clusters are a unique class of materials as they comprise the bridge between molecular-regime scales to larger-sized structures. Recently, very stable clusters (magic-sized clusters) were discovered; a cluster with a definite geometric structure that exhibits a high degree of chemical and physical stability (Kasuya et al. 2004). The potential applications of these clusters are novel and featured. $(\mathrm{CdSe})_{2}$ is the minimal stoichiometric $\mathrm{CdSe}$ cluster, which gives it a distinguished status as it can be the building block of larger nano-sized structures. Owing to the wide mixed ionic-covalent bonding possibilities of $\mathrm{Cd}$ and $\mathrm{Se}$ atoms, this cluster can be found in more than one isomer. Many of the computational works were performed on $(\mathrm{CdSe})_{2}$ clusters to determine their structural, electronic and optical properties. Computational works performed by Cui et al. (2015), Deglmann et al. (2002), Karamanis et al. (2006a, 2006b), Nguyen et al. (2013), Sen and Chakrabarti (2006), Troparevsky et al. (2001), Troparevsky and Chelikowsky (2000), and Yang et al. (2008) showed many aspects of $(\mathrm{CdSe})_{2}$ clusters. However, the majority of the previous studies reported the properties of the most stable isomer only.

Determining the absorption spectrum of the cluster plays a crucial role to investigate the cluster experimentally. Also, it is a valuable mean to compare theoretical with experimental studies. Many experimental works reported the absorption spectra of ultra-small CdSe structures (Brioude et al. 2004; Dolai et al. 2013; Jose et al. 2006; Kasuya et al. 2004; Kuçur et al. 2008; Kudera et al. 2007; Liu et al. 2011; Ouyang et al. 2008; Peng \& Peng 2002; Riehle et al. 2009; Sathyamoorthy et al. 2007; Wang et al. 2004; Wu et al. 2007; Xia \& Zhu 2008). In all these experimental works, the absorption spectra of CdSe clusters were reported. However, it was difficult to assign the absorption peaks with their corresponding sources, and therefore the absorption spectra graphs require theoretical studies to illustrate it. Computation and simulation are valuable tools to predict and analyze experimental observations. Moreover, the 
structure determination is experimentally intractable, and the spectroscopic measurements are indirect and insufficient (Azpiroz et al. 2013). Furthermore, isolation of the cluster from surrounding atoms for investigation is a formidable issue. Accordingly, the most stable (the lowest energy) isomer will have the uppermost influence on the cluster spectrum as well as the shape and size (Gutsev et al. 2015). Consequently, determining the possible $(\mathrm{CdSe})_{2}$ isomers is an intriguing subject; hence the diverse properties of the isomers are required theoretically and experimentally, as these properties will control the larger clusters and the bulk material (Peterson et al. 2007).

\section{MATERIALS AND METHODS}

\section{GEOMETRY OPTIMIZATION AND ELECTRONIC PROPERTIES}

In order to study any physical or chemical properties, the first step is to ascertain the preferred structure of $(\mathrm{CdSe})_{2}$ cluster. The geometry optimization calculations to reach full geometry relaxation were performed using the Abinit package (Gonze et al. 2016). This package carries out the optimization approach by using the modified efficient Broyden-Fletcher-Goldfarb-Shanno minimization (BFGS) algorithm (Sheppard et al. 2008). Abinit adopts pseudopotentials and a planewave basis method under local density approximation (LDA) within the framework of density functional theory (DFT). The pseudopotentials and a planewave basis method is the most practical computational method used due to its simplicity to calculate forces and stresses. Furthermore, convergence can be improved by controlling the single cutoff energy parameter. Therefore, forces and stresses of DFT are used to determine the global and local energy minima, which will be utilized to obtain the geometry optimization structure, consequently leading to the determination of the stable isomers. While the calculations are associated with establishing the most stable isomer, on the other hand, the non-converged isomers are related to other fewer unstable isomers.

The variables' values prior to the calculations were selected carefully to ensure more accuracy. The following values were employed: A large cubic unit cell with dimensions of $11 \AA$; to ensure that the initial structure is isolated from the neighboring interactions, cutoff energy of $1361 \mathrm{eV}$; this controls the number of planewaves at a given $\mathrm{k}$ point; where the high value was employed to get better convergence, the BFGS algorithm geometry optimization stopping criterion, which stops the algorithm structural relaxation iteration was set to $5.0 \times 10^{-5}$ Hartree/Bohr. The same value was also used to stop the self-consistent field cycle once the convergence between two successive iterations' differences is reached, (Goedecker et al. 1996) spinpolarized LDA for exchange-correlation functional, and
(Troullier \& Martins 1991) pseudopotential, where the valence electrons for $\mathrm{Cd}$, Se atoms were $4 \mathrm{~d}^{10} 5 \mathrm{~s}^{2}$, and $4 \mathrm{~s}^{2}$ $4 p^{4}$, respectively.

Twenty possible isomers were tested with the converged isomers listed in Figure 1. The initial possible isomers' structures that did not converge according to the constructed criteria are listed in Figure 2. The same parameters were used to calculate the electronic properties of the isomers.

\section{OPTICAL PROPERTIES}

Octopus package was used to calculate the isomers' absorption spectra, where this code follows the timedependent density functional theory (TDDFT) in Casida formalism (Andrade et al. 2015; Casida et al. 1998). Octopus performs the calculations by first implementing the ground-state density calculations (here, the final geometric structures were introduced from the Abinit calculations). Then unoccupied states' calculations were performed, followed by calculating the oscillator strength; a physical quantity that represents the number of electric dipole oscillators the external field can stimulate, then the strength function (another physical quantity represents the average of oscillator strength over the three directions) were computed. Finally, the absorption spectrum of the system between the energy and the strength function is obtained. Furthermore, the parameters implemented in Octopus were chosen to ensure a great deal of accuracy; Troullier-Martins pseudopotential type (Troullier \& Martins 1991), and Perdew-Zunger local density approximation (LDA) for the exchange-correlation potential (Perdew \& Zunger 1981) were implemented. A grid spacing of $0.175 \AA$ was employed for the real-space grid calculations where the relative convergence of the density was set to $1.0 \times 10^{-7}$ $\left(\mathrm{el} / \mathrm{Bohr}^{3}\right)$, likewise, grid cutoff energy was set to 1228 $\mathrm{eV}$.

\section{RESULTS AND DISCUSSION}

\section{STRUCTURAL PROPERTIES}

From Figures 1 and 2, it can be seen that nine of the initially proposed structures did not converge, while the other eleven converged. The non-converged isomers imply that there is a weak possibility of their presence in any experiment. All the converged isomers' structures are 2D planar, and none of the converged structures are 3D. Although the initial structures of the converged isomers are different, nevertheless, the final structures represent three distinctive structures; three rhombus subgroups: (R1) where the shorter diagonal of the rhombus is occupied by Cd atoms; (I1, I2, I3), (R2) where the Cd atoms occupy the longer diagonal; (I4, I5, I6), then two trapezoids (I7 and I8). Finally, three linear-like structures (I9, I10, and I11), I10 are very close to trigonal planar 
but have Cs point group symmetry. For the upcoming discussion and for the sake of abbreviation, I1 will be taken as a representative of the first rhombus subgroup (R1), I4 to represent the second rhombus subgroup (R2) and I7 to represent trapezoidal-subgroup.

The Cd-Se bond lengths are depicted in Table 1 . Excluding the $2 \AA$ of I7, the remaining values are between 2.50 and $2.74 \AA$. I11 isomer showed an interesting shape as it deviated from complete linearity. The $\mathrm{Cd}$-Se bond length is $2.7 \AA$, which is a higher value compared with other isomers; which may be attributed to the strong repulsion between the $\mathrm{Cd}_{2}$ and $\mathrm{Se}_{2}$ constituents. For rhombus (R1), the obtained results are very close to the previous studies as depicted in Table 1. Also, it can be observed that the bond length for the first rhombus (R1) subgroup is lower than the second subgroup by $0.11 \AA$, which can corroborate that R1 is more stable.

The angles between the neighboring atoms are shown in Table 1. The Cd-Se-Cd angle values showed an impressive remark as the $\mathrm{Cd}$ atoms exchanged their positions with the $\mathrm{Se}$ atoms, but with reversed angles deviation of about $10^{\circ}$. In the first rhombus subgroup (R1), the $\mathrm{Cd}-\mathrm{Se}-\mathrm{Cd}$ angle is the lower angle, while in the second rhombus subgroup (R2), the Se-Cd-Se angle is the lower one. This is comparable with Nguyen et al. (2013), which gives an indication that R2 is less stable. I7 angles showed that deviation from the complete square is very narrow. Karamanis et al. (2006), Matxain et al. (2004), Sanville et al. (2006), and Sen and Chakrabarti (2006) reported that the Se-Cd-Se angle values of the rhombus isomer were 93.8, 113.2, 113.2, and $111.96^{\circ}$, respectively, which in fact, nicely validates the results of this work $\left(114.17^{\circ}\right)$.

\section{ELECTRONIC PROPERTIES}

Table 2 demonstrates the total ground state energy values with the relative energy differences, where it can be seen that energy values are comparable, with a difference of $1.82 \mathrm{eV}$ from highest to lowest. The least energy's isomer is I1, while I9 is the largest; the differences between the subgroups are miniature. It can be noticed that the relative energy differences obtained from this work are close to works of Cui et al. (2015) and Deglmann et al. (2002), as shown in Table 2. The energy values showed that the R1 structure is the most stable isomer; likewise, all the previous (CdSe) $)_{2}$ clusters works reported the same outcome (Cui et al. 2015; Deglmann et al. 2002; Farrow et al. 2014; Karamanis et al. 2006; Matxain et al. 2004; Sanville et al. 2006; Sen \& Chakrabarti 2006; Yang et al. 2008). Moreover, this can be extended to the highest degree of II-VI semiconductor clusters, ZnS, CdTe, ZnTe, and ZnSe (Bhattacharya \& Kshirsagar 2007; Burnin et al. 2005; Matxain et al. 2004). Furthermore, the trapezoid structure is the second stable isomer, which was reported by (Burnin et al. 2005; Deglmann et al. 2002; Matxain et al. 2001; Nguyen et al. 2013). To the best of our knowledge, all the performed geometry optimization calculations of the stoichiometric structures (CdSe), showed that the most stable structure is the rhombus (R1), followed by the trapezoid, and in particular, the rhombus (R2) structure follows. On the other hand, in this study, I11 isomer gave energy value, which places it in the third stable isomer. I9 and I12 are the last two isomers.

Table 2 also demonstrates that the HOMO-LUMO (H-L) gap for the R1 rhombus is $1.2 \mathrm{eV}$, while it is 0.6 for the R2 rhombus, accompanied by the trapezoidal structure. The planar subgroup (I9, I10, and I11) showed the smallest H-L gap. Consequently, it can be concluded that the R1 rhombus is the most stable isomer of II-VI semiconductor clusters, in accordance with Joswig et al. (2002). The highest gaps are associated with lower energy values. The same trend was also reported by Troparevsky and Chelikowsky (2000), this connection was emphasized in Figure 3. It can be deduced that the H-L gap depends on the clusters' structure, rather than the size.

Since the Cd-Se bond is partially ionic, the charge density of the bonding electrons is localized around the Se atoms, making it as a negative ion, leaving the $\mathrm{Cd}$ atom as a positive ion. Therefore, the existence of two lone electron pairs around the selenium atom enhances the non-linear structure of the converged isomers.

\section{OPTICAL PROPERTIES}

Figure 4 illustrates the absorption spectra of $(\mathrm{CdSe})_{2}$ stable isomers, except the spectrum of I11 isomer. The code could not complete the calculations, which implies that the structure of the isomer is weak. Although the graphs represent only $(\mathrm{CdSe})_{2}$ isomers, there were significant differences among them. The graphs were characterized by a strong optical response in the 4.87$7.70 \mathrm{eV}$ region; most of the isomers exhibit 2-3 major peaks. In addition, the strength function values were 1.07-6.24. Consequently, each isomer can be traced in any practical experiment by its optical spectrum, which can be considered as a distinct fingerprint of each isomer. Table 3 summarizes the main optical properties of the $(\mathrm{CdSe})$, isomers. Firstly, when comparing this study's values with other computational works, only two previous studies regarding $(\mathrm{CdSe})_{2}$ absorption spectra were found, and both reported the absorption spectra of the most stable isomer, namely I1 isomer. Troparevsky et al. (2001) and Cui et al. (2015) calculated the absorption spectra of small CdSe clusters. The results showed that the $(\mathrm{CdSe})_{2}$ main peak in the calculated absorption spectra was located at $(7.9,8.5 \mathrm{eV})$, respectively. For the same isomer, our results generated two main peaks located at 6.34 , and $7.70 \mathrm{eV}$. The $7.70 \mathrm{eV}$ peak is very close to the value of $7.90 \mathrm{eV}$ and around $10 \%$ less than the 8.5. Secondly, a comparison of this work's results with related experimental works; Wu et al. (2007) synthesized molecular-size bare CdSe clusters using the electroporation of synthetic dioleoylphosphatidylcholine vesicles method. The measured absorption spectra of 
CdSe clusters were recorded and the peaks evolved with time. The first four peaks were $256 \mathrm{~nm}(4.84 \mathrm{eV}), 215$ $\mathrm{nm}(5.71 \mathrm{eV}), 227 \mathrm{~nm}(5.46 \mathrm{eV})$, and $247 \mathrm{~nm}(5.02 \mathrm{eV})$, respectively. It was not possible to assign the cluster size with its associated absorption spectrum as it was stated that $256 \mathrm{~nm}$ main peak either belongs to $(\mathrm{CdSe})_{1}$ or $(\mathrm{CdSe})_{2}$. In this study calculations, this peak is located in the range of (CdSe), clusters' peaks, which conclude that the source of this peak $(256 \mathrm{~nm})$ is $\mathrm{I} 7$ isomer; where it detects a peak at $254.6 \mathrm{~nm}$. Peng and Peng (2002) found an absorption peak at $285 \mathrm{~nm}(4.35 \mathrm{eV})$ that was attributed to a small structure of CdSe nanocluster with less than four $\mathrm{Cd}$ atoms. From Table 3, it can be seen that I10 isomer gave $4.41 \mathrm{eV}$ for the first main peak. The closely two values imply that I10 might be the source of the experimental peak. Comparing the values of Table 3 with other experimental data reported by Brioude et al. (2004), Dolai et al. (2013), Dukes et al. (2010), Jose et al. (2006), Ouyang et al. (2008), Sathyamoorthy et al. (2007), Wang et al. (2004) and Xia and Zhu (2008) showed that this work values are much smaller (when studying the wavelength in $\mathrm{nm})$. Thus, either the (CdSe) clusters are difficult to trace in experiments, or they are strongly reactive that they will straightforwardly react to produce larger clusters.

TABLE 1. Structural properties of the (CdSe) $)_{2}$ converged

\begin{tabular}{|l|l|l|l|l|l|}
\hline Isomer & Initial Structure & $\begin{array}{c}\text { Final } \\
\text { Structure }\end{array}$ & Isomer & Initial Structure & Final Structure \\
\hline & & 1 & & & \\
\hline
\end{tabular}

FIGURE 1. Converged (CdSe) $)_{2}$ Isomers, gray colour for $\mathrm{Cd}$ atom and blue for $\mathrm{Se}$ atom, 1 and 2 are the labels of the atoms 


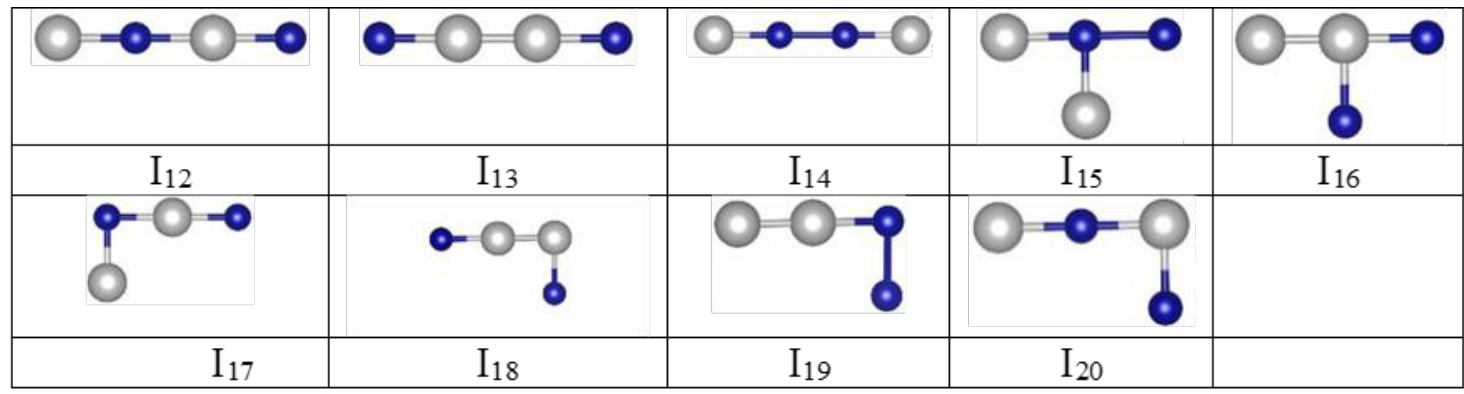

FIGURE 2. Non-converged (CdSe) $)_{2}$ isomers, gray colour for $\mathrm{Cd}$ atom and blue for Se atom

isomers, B.L $(\AA)$ : Cd-Se bond length, An. $1\left(^{\circ}\right)$, An. $2\left(^{\circ}\right)$, An. $3\left(^{\circ}\right)$, An. $4\left(^{\circ}\right)$, are Cd-Se-Cd, Se-Cd-Se, Cd-Se-Se, Cd-Cd-Se bond angles, respectively

\begin{tabular}{|c|c|c|c|c|c|}
\hline Isomer & B.L & An. 1 & An. 2 & An. 3 & An. 4 \\
\hline $\mathrm{I}_{1}$ & $\begin{array}{c}2.53 \text { (this work), } 2.6 \text { (Deglmann } \\
\text { et al. 2002), 2.6-2.7 (Matxain et } \\
\text { al. 2004), 2.6 (Sen \& Chakrabarti } \\
\text { 2006), 2.6 (Karamanis et al. } \\
\text { 2006), 2.6 (Sanville et al. 2006), } \\
\text { 2.3-2.8 (Yang et al. 2008), 2.5 } \\
\text { (Farrow et al. 2014) 2.6-2.7 (Cui } \\
\text { et al. 2015) }\end{array}$ & 65.83 & 114.17 & - & - \\
\hline $\mathrm{I}_{4}$ & 2.64 & 123.72 & 56.28 & - & - \\
\hline $\mathrm{I}_{7}$ & 2.03 & - & - & 87.01 & 93.00 \\
\hline $\mathrm{I}_{9}$ & 2.50 & 116.32 & 69.75 & - & - \\
\hline $\mathrm{I}_{10}$ & 2.68 & 64.48 & - & 147.74 & - \\
\hline $\mathrm{I}_{11}$ & 2.70 & - & - & 152.76 & 152.84 \\
\hline
\end{tabular}

TABLE 2. Electronic properties of $(\mathrm{CdSe})_{2}$ converged isomers, T.E $(\mathrm{eV})$ : total energy, $\triangle \mathrm{E}(\mathrm{eV})$ : total energy difference from the first isomer, H-L (eV): HOMO-LUMO gap

\begin{tabular}{lccc}
\hline Isomer & T.E & $\Delta \mathrm{E}$ & H-L \\
\hline $\mathrm{I}_{1}$ & -3540.27 & 0.00 & $\begin{array}{c}1.20 \text { [this work], 1.5 (Troparevsky \& } \\
\text { Chelikowsky 2000), 2.4 (Karamanis } \\
\text { et al. 2006), (1.7-3.6) (Yang et al. } \\
\text { 2008), 1.26 (Farrow et al. 2014), and } \\
\text { 2.6 (Cui et al. 2015) }\end{array}$ \\
$\mathrm{I}_{7}$ & -3539.97 & 0.30 & 0.59 \\
$\mathrm{I}_{11}$ & -3539.89 & 0.38 & 0.10 \\
$\mathrm{I}_{4}$ & -3539.33 & 0.94 & 0.60 \\
$\mathrm{I}_{10}$ & -3539.06 & 1.21 & 0.21 \\
$\mathrm{I}_{9}$ & -3538.45 & 1.82 & 0.29 \\
\hline
\end{tabular}




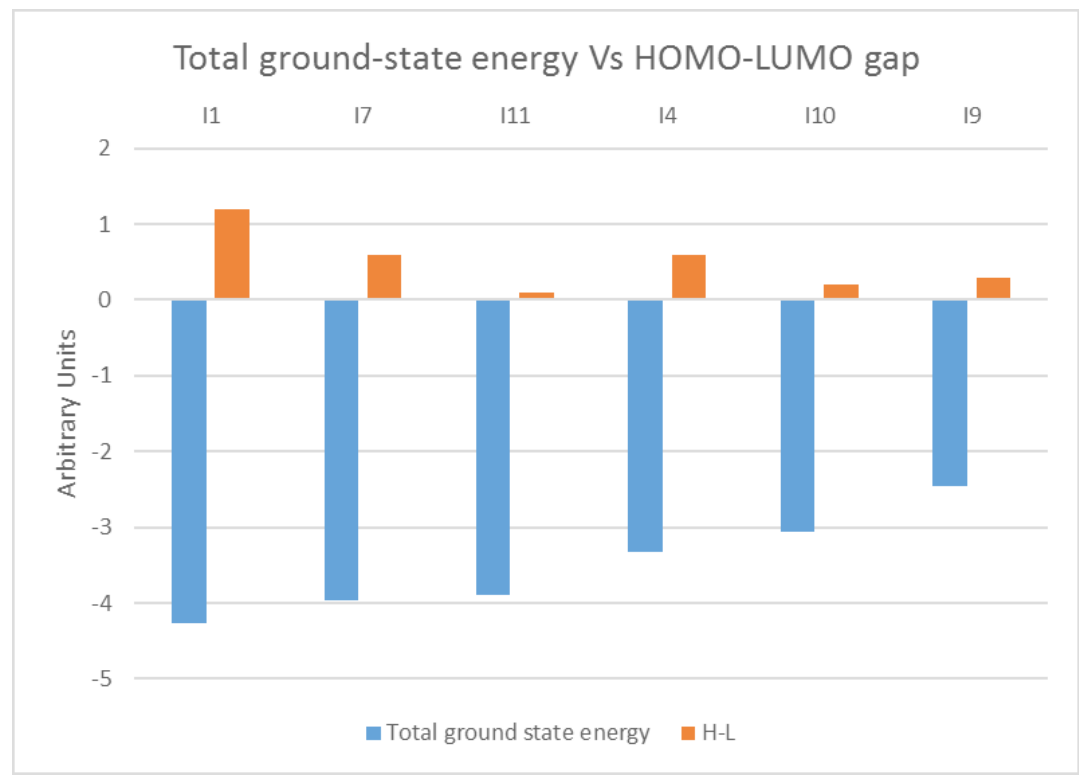

FIGURE 3. Total Energy (T.E) with HOMO-LUMO gap correlation of $(\mathrm{CdSe})_{2}$ stable isomers

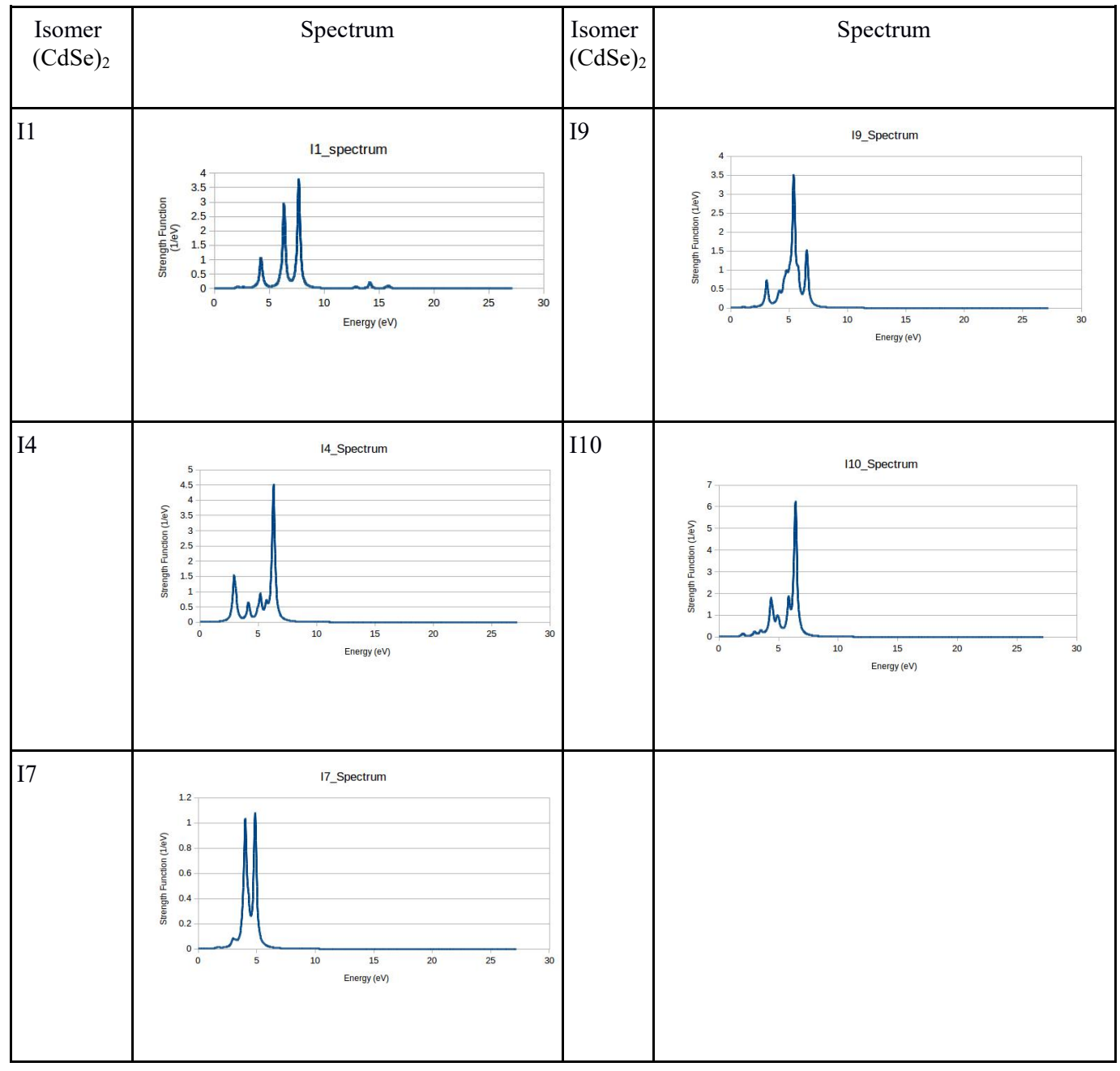

FIGURE 4. Absorption spectra of $(\mathrm{CdSe})_{2}$ stable isomers 
TABLE 3. Optical properties of (CdSe $)_{2}$ stable isomers

\begin{tabular}{lcccc}
\hline $\begin{array}{c}\text { Isomer } \\
(\mathrm{CdSe})_{2}\end{array}$ & $\begin{array}{c}\text { First main } \\
\text { peak }\end{array}$ & Second peak & $\begin{array}{c}\text { Absorption } \\
\text { edge }\end{array}$ & $\begin{array}{c}\text { Max. strength } \\
\text { function }\end{array}$ \\
\hline $\mathrm{I} 1$ & 6.34 & 7.70 & 4.27 & 3.79 \\
$\mathrm{I} 4$ & 2.97 & 6.31 & 2.53 & 4.5 \\
$\mathrm{I} 7$ & 4.00 & 4.87 & 3.15 & 1.07 \\
$\mathrm{I} 9$ & 5.39 & 6.56 & 3.13 & 3.50 \\
$\mathrm{I} 10$ & 4.41 & 6.39 & 3.07 & 6.24 \\
\hline
\end{tabular}

\section{CONCLUSION}

After the most stable (converged) isomers were estimated, the structures' properties were specified; bond lengths, bond angles, total ground-state energy, HOMO-LUMO orbitals, and gaps were calculated. Our results supported previously published works remarkably. In this study, six stable isomers for $(\mathrm{CdSe})_{2}$ were found: the most stable isomer was the rhombus structure, which was also reported by previous studies. Bond lengths and bond angles were also in accordance with these studies. The rhombus $\mathrm{Cd}-\mathrm{Se}$ bond length calculations generated 2.53 $\AA$, the $\mathrm{Cd}-\mathrm{Se}-\mathrm{Cd}$ and, the $\mathrm{Se}-\mathrm{Cd}-\mathrm{Se}$ angles were $65.8^{\circ}$, $114.2^{\circ}$, respectively. The HOMO-LUMO graphs indicated that in the HOMO orbital, the electrons localized primarily closer to Se atom, while in the LUMO orbital, the electrons will be partially localized around $\mathrm{Se}$ and $\mathrm{Cd}$ atoms. All results are supported by previous studies.

\section{REFERENCES}

Alivisatos, P. 2003. The use of nanocrystals in biological detection. Nature Biotechnology 22: 47-52.

Andrade, X., Strubbe, D., De Giovannini, U., Larsen, A.H., Oliveira, M.J.T., Alberdi-Rodriguez, J., Varas, A., Theophilou, I., Helbig, N., Verstraete, M.J., Stella, L., Nogueira, F., Aspuru-Guzik, A., Castro, A., Marques, M.A.L. \& Rubio, A. 2015. Real-space grids and the Octopus code as tools for the development of new simulation approaches for electronic systems. Physical Chemistry Chemical Physics 17(47): 31371-31396.

Atchison, J.S. \& Schauer, C.L. 2011. Fabrication and characterization of electrospun semiconductor nanoparticle - Polyelectrolyte ultra-fine fiber composites for sensing applications. Sensors (Basel, Switzerland) 11(11): 1037210387.

Azpiroz, J.M., Matxain, J.M., Infante, I., Lopez, X. \& Ugalde, J.M. 2013. A DFT/TDDFT study on the optoelectronic properties of the amine-capped magic $(\mathrm{CdSe}) 13$ nanocluster. Physical Chemistry Chemical Physics 15(26): 1099611005 .

Bhattacharya, S.K. \& Kshirsagar, A. 2007. Ab initio calculations of structural and electronic properties of CdTe clusters. Physical Review B 75(3): 035402.
Brioude, A., Bellessa, J., Rabaste, S., Champagnon, B., Sphanel, L., Mugnier, J. \& Plenet, J.C. 2004. Resonant Raman effect enhanced by surface plasmon excitation of CdSe nanocrystals embedded in thin $\mathrm{SiO}_{2}$ films. Journal of Applied Physics 95(5): 2744-2748.

Burnin, A., Sanville, E. \& BelBruno, J.J. 2005. Experimental and computational study of the $\mathrm{ZnnSn}$ and $\mathrm{ZnnSn}+$ Clusters. The Journal of Physical Chemistry A 109(23): 5026-5034.

Casida, M.E., Jamorski, C., Casida, K.C. \& Salahub, D.R. 1998. Molecular excitation energies to high-lying bound states from time-dependent density-functional response theory: Characterization and correction of the time-dependent local density approximation ionization threshold. The Journal of Chemical Physics 108(11): 4439-4449.

Chen, O., Zhao, J., Chauhan, V.P., Cui, J., Wong, C., Harris, D.K., Wei, H., Han, H.S., Fukumura, D., Jain, R.K. \& Bawendi, M.G. 2013. Compact high-quality CdSe$\mathrm{CdS}$ core-shell nanocrystals with narrow emission linewidths and suppressed blinking. Nature Materials 12: 445-451.

Cossairt, B.M. \& Owen, J.S. 2011. CdSe clusters: At the interface of small molecules and quantum dots. Chemistry of Materials 23(12): 3114-3119.

Cui, Y., Lou, Z., Wang, X., Yu, S. \& Yang, M. 2015. A study of optical absorption of cysteine-capped CdSe nanoclusters using first-principles calculations. Physical Chemistry Chemical Physics 17(14): 9222-9230.

Deglmann, P., Ahlrichs, R. \& Tsereteli, K. 2002. Theoretical studies of ligand-free cadmium selenide and related semiconductor clusters. The Journal of Chemical Physics 116(4): 1585-1597.

Dolai, S., Dass, A. \& Sardar, R. 2013. Photophysical and redox properties of molecule-like CdSe nanoclusters. Langmuir 29(20): 6187-6193

Dukes, A.D., McBride, J.R. \& Rosenthal, S.J. 2010. Synthesis of magic-sized $\mathrm{CdSe}$ and $\mathrm{CdTe}$ nanocrystals with diisooctylphosphinic acid. Chemistry of Materials 22(23): 6402-6408.

Farrow, M.R., Chow, Y. \& Woodley, S.M. 2014. Structure prediction of nanoclusters; A direct or a pre-screened search on the DFT energy landscape? Physical Chemistry Chemical Physics 16(39): 21119-21134. 
Goedecker, S., Teter, M. \& Hutter, J. 1996. Separable dualspace Gaussian pseudopotentials. Physical Review B 54(3): 1703-1710.

Gonze, X., Jollet, F., Abreu Araujo, F., Adams, D., Amadon, B., Applencourt, T., Audouze, C., Beuken, J.M., Bieder, J., Bokhanchuk, A., Bousquet, E., Bruneval, F., Caliste, D., Côté, M., Dahm, F., Da Pieve, F., Delaveau, M., Di Gennaro, M., Dorado, B., Espejo, C., Geneste, G., Genovese, L., Gerossier, A., Giantomassi, M., Gillet, Y., Hamann, D.R., He, L., Jomard, G., Laflamme Janssen, J., Le Roux, S., Levitt, A., Lherbier, A., Liu, F., Lukačević, I., Martin, A., Martins, C., Oliveira, M.J.T., Poncé, S., Pouillon, Y., Rangel, T., Rignanese, G.M., Romero, A.H., Rousseau, B., Rubel, O., Shukri, A.A., Stankovski, M., Torrent, M., Van Setten, M.J., Van Troeye, B., Verstraete, M.J., Waroquiers, D., Wiktor, J., Xu, B., Zhou, A. \& Zwanziger, J.W. 2016. Recent developments in the ABINIT software package. Computer Physics Communications 205: 106-131.

Gutsev, L.G., Dalal, N.S., Ramachandran, B.R., Weatherford, C.A. \& Gutsev, G.L. 2015. Spectral signatures of semiconductor clusters: (CdSe)16 isomers. Chemical Physics Letters 636: 121-128.

Jose, R., Zhanpeisov, N.U., Fukumura, H., Baba, Y. \& Ishikawa, M. 2006. Structure-property correlation of CdSe clusters using experimental results and first-principles DFT calculations. Journal of the American Chemical Society 128(2): 629-636.

Joswig, J.O., Roy, S., Sarkar, P. \& Springborg, M. 2002. Stability and bandgap of semiconductor clusters. Chemical Physics Letters 365(1): 75-81.

Karamanis, P., Maroulis, G. \& Pouchan, C. 2006a. Basis set and electron correlation effects in all-electron $a b$ initio calculations of the static dipole polarizability of small cadmium selenide clusters, (CdSe)n, $n=1,2,3,4$. Chemical Physics 331(1): 19-25.

Karamanis, P., Maroulis, G. \& Pouchan, C. 2006b. Molecular geometry and polarizability of small cadmium selenide clusters from all-electron $a b$ initio and density functional theory calculations. The Journal of Chemical Physics 124(7): 071101.

Kasuya, A., Sivamohan, R., Barnakov, Y.A., Dmitruk, I.M., Nirasawa, T., Romanyuk, V.R., Kumar, V., Mamykin, S.V., Tohji, K., Jeyadevan, B., Shinoda, K., Kudo, T., Terasaki, O., Liu, Z.R., Belosludov, V., Sundararajan, V. \& Kawazoe, Y. 2004. Ultra-stable nanoparticles of CdSe revealed from mass spectrometry. Nature Materials 3: 99-102.

Kilina, S., Kilin, D. \& Tretiak, S. 2015. Light-driven and phonon-assisted dynamics in organic and semiconductor nanostructures. Chemical Reviews 115(12): 5929-5978.

Kim, T.H., Cho, K.S., Lee, E.K., Lee, S.J., Chae, J., Kim, J.W., Kim, D.H., Kwon, J.Y., Amaratunga, G., Lee, S.Y., Choi, B.L., Kuk, Y., Kim, J.M. \& Kim, K. 2011. Full-colour quantum dot displays fabricated by transfer printing. Nature Photonics 5: 176-182.

Kisslinger, R., Hua, W. \& Shankar, K. 2017. Bulk heterojunction solar cells based on blends of conjugated polymers with ii-vi and iv-vi inorganic semiconductor quantum dots. Polymers 9(2): 35.

Kolobkova, E.V., Kukushkin, D.S., Nikonorov, N.V., Sidorov, A.I. \& Shakhverdov, T.A. 2015. Luminescent properties of fluorophosphate glasses with molecular cadmium selenide clusters. Optics and Spectroscopy 118(2): 224-228.

Kuçur, E., Ziegler, J. \& Nann, T. 2008. Synthesis and spectroscopic characterization of fluorescent blue-emitting ultrastable CdSe clusters. Small 4(7): 883-887.

Kudera, S., Zanella, M., Giannini, C., Rizzo, A., Li, Y., Gigli, G., Cingolani, R., Ciccarella, G., Spahl, W., Parak, W.J. \& Manna, L. 2007. Sequential growth of magic-size CdSe nanocrystals. Advanced Materials 19(4): 548-552.

Lee, S.R., Kim, D.S. \& Choi, S.H. 2017. The conjugated phenylene polymer-modified photoanodes for quantum dot-sensitized solar cells. Journal of Nanomaterials 2017: Article ID. 9048279.

Liu, Y.H., Wang, F., Wang, Y., Gibbons, P.C. \& Buhro, W.E. 2011. Lamellar assembly of cadmium selenide nanoclusters into quantum belts. Journal of the American Chemical Society 133(42): 17005-17013.

Majdabadi, A., Gaeeni, M.R., Ghamsari, M.S. \& Majles-Ara, M.H. 2015. Investigation of stability and nonlinear optical properties CdSe colloidal nanocrystals. Journal of Laser Applications 27(2): 022010.

Matxain, J.M., Mercero, J.M., Fowler, J.E. \& Ugalde, J.M. 2004. Clusters of II-VI materials: $\mathrm{Cd} \mathrm{X}, \mathrm{X}=\mathrm{S}, \mathrm{Se}, \mathrm{Te}, \mathrm{i} \leq 16$. The Journal of Physical Chemistry A 108(47): 10502-10508.

Matxain, J.M., Mercero, J.M., Fowler, J.E. \& Ugalde, J.M. 2001. Small clusters of group-(II-VI) materials: Zni Xi, X=Se,Te, $\mathrm{i}=1-9$. Physical Review A 64(5): 053201.

Nguyen, K.A., Pachter, R. \& Day, P.N. 2013. Computational prediction of structures and optical excitations for nanoscale ultrasmall $\mathrm{ZnS}$ and CdSe clusters. Journal of Chemical Theory and Computation 9(8): 3581-3596.

Ouyang, J., Zaman, M.B., Yan, F.J., Johnston, D., Li, G., Wu, X., Leek, D., Ratcliffe, C.I., Ripmeester, J.A. \& Yu, K. 2008. Multiple families of magic-sized CdSe nanocrystals with strong bandgap photoluminescence via noninjection one-pot syntheses. The Journal of Physical Chemistry $C$ 112(36): 13805-13811.

Peng, Z.A. \& Peng, X. 2002. Nearly monodisperse and shape-controlled CdSe nanocrystals via alternative routes: Nucleation and growth. Journal of the American Chemical Society 124(13): 3343-3353.

Perdew, J.P. \& Zunger, A. 1981. Self-interaction correction to density-functional approximations for many-electron systems. Physical Review B 23(10): 5048-5079.

Peterson, K.A., Shepler, B.C. \& Singleton, J.M. 2007. The group 12 metal chalcogenides: An accurate multireference configuration interaction and coupled cluster study. Molecular Physics 105(9): 1139-1155.

Renner, J., Worschech, L., Forchel, A., Mahapatra, S. \& Brunner, K. 2006. CdSe quantum dot microdisk laser. Applied Physics Letters 89(23): 231104.

Riehle, F.S., Bienert, R., Thomann, R., Urban, G.A. \& Krüger, M. 2009. Blue luminescence and superstructures from magic size clusters of CdSe. Nano Letters 9(2): 514-518.

Sanville, E., Burnin, A. \& BelBruno, J.J. 2006. Experimental and computational study of small $(n=1-16)$ stoichiometric zinc and cadmium chalcogenide clusters. The Journal of Physical Chemistry A 110(7): 2378-2386.

Sathyamoorthy, R., Manjuladevi, V., Sudhagar, P., Senthilarasu, S. \& Pal, U. 2007. Surfactant-assisted room-temperature 
synthesis of CdSe nanoclusters. Materials Chemistry and Physics 105(1): 20-24.

Schreuder, M.A., Xiao, K., Ivanov, I.N., Weiss, S.M. \& Rosenthal, S.J. 2010. White light-emitting diodes based on ultrasmall CdSe nanocrystal electroluminescence. Nano Letters 10(2): 573-576.

Sen, S. \& Chakrabarti, S. 2006. Frequency-dependent nonlinear optical properties of CdSe clusters. Physical Review $B$ 74(20): 205435.

Sheppard, D., Terrell, R. \& Henkelman, G. 2008. Optimization methods for finding minimum energy paths. The Journal of Chemical Physics 128(13): 134106.

Stinner, F.S., Lai, Y., Straus, D.B., Diroll, B.T., Kim, D.K., Murray, C.B. \& Kagan, C.R. 2015. Flexible, high-speed CdSe nanocrystal integrated circuits. Nano Letters 15(10): 7155-7160.

Tao, Z., Huang, Y., Liu, X., Chen, J., Lei, W., Wang, X., Pan, L., Pan, J., Huang, Q. \& Zhang, Z. 2016. High-performance photo-modulated thin-film transistor based on quantum dots/reduced graphene oxide fragment-decorated $\mathrm{ZnO}$ nanowires. Nano-Micro Letters 8(3): 247-253.

Troparevsky, M.C. \& Chelikowsky, J.R. 2000. Structural and electronic properties of $\mathrm{CdS}$ and $\mathrm{CdSe}$ clusters. The Journal of Chemical Physics 114(2): 943-949.

Troparevsky, M.C., Kronik, L. \& Chelikowsky, J.R. 2001. Ab initio absorption spectra of CdSe clusters. Physical Review $B$ 65(3): 033311.

Troullier, N. \& Martins, J.L. 1991. Efficient pseudopotentials for plane-wave calculations. Physical Review B 43(3): 1993-2006.

Wang, H., Tashiro, A., Nakamura, H., Uehara, M., Miyazaki, M., Watari, T. \& Maeda, H. 2004. Synthesis of CdSe magicsized nanocluster and its effect on nanocrystal preparation in a microfluidic reactor. Journal of Materials Research 19(11): 3157-3161.
Wu, S., Liu, H., Liu, H., Wu, Z., Du, Z. \& Schelly, Z.A. 2007. Synthesis and bandgap variation of molecular-size CdSe clusters via electroporation of vesicles. Nanotechnology 18(48): 485607.

Xia, Y.S. \& Zhu, C.Q. 2008. Aqueous synthesis of luminescent magic sized CdSe nanoclusters. Materials Letters 62(14): 2103-2105.

Yang, P., Tretiak, S., Masunov, A.E. \& Ivanov, S. 2008. Quantum chemistry of the minimal CdSe clusters. The Journal of Chemical Physics 129(7): 074709.

Yu-Zhang, K., Guo, D.Z., Mallet, J., Molinari, M., Loualiche, A. \& Troyon, M. 2008. Electrodeposition and characterization of CdSe semiconducting nanowires. Journal of Nanoscience and Nanotechnology 8(4): 2022-2028.

Yu, P. \& Cardona, M. 2010. Fundamentals of Semiconductors. Berlin Heidelberg, Springer-Verlag Berlin Heidelberg.

A.I.A. Alselawe*, MHH Jumali \& G. Gopir School of Applied Physics

Faculty of Science and Technology

Universiti Kebangsaan Malaysia

43600 UKM Bangi, Selangor Darul Ehsan

Malaysia

M.M. Anas

Fakulti Sains dan Teknologi

Universiti Sains Islam Malaysia (USIM)

Bandar Baru Nilai

71800 Nilai, Negeri Sembilan Darul Khusus

Malaysia

*Corresponding author; email: n.salameh111@gmail.com

Received: 17 December 2019

Accepted: 24 February 2020 